typic expression in families with identical $\mathrm{X}$ chromosome abnormalities and non-random inactivation are the result of the differences in the genetic content of the normal, active $\mathrm{X}^{7}$ The mental retardation or dysmorphic features or both in the proband could, therefore, be the result of the expression of genes on the normal $\mathrm{X}$ which is active in all the cells.

\section{References}

${ }^{1}$ Nielson LB, Boczkowski K, Mikkelsen M, Dahl G, Andersen $\mathrm{E}$. Partial Turner's syndrome in four girls with $\mathrm{Xq}$ duplication and Xp deficiency. Hum Genet 1982;61:12-7.

2 Nikolis J, Stolevic E. Recombinant chromosome as a result of pericentric inversion of X chromosome. Hum Genet 1978;45: $115-22$.
${ }^{3}$ Trunca C, Therman E, Rosenwaks Z. The phenotypic effects of small, distal Xq deletions. Hum Genet 1984;68:87-9.

${ }^{4}$ Keitges EA, Palmer CG, Weaver DD. Pericentric X inversion in dizygotic twins who differ in $\mathrm{X}$ chromosome inactivation and menstrual cycle function. Hum Genet 1982;62:210-3.

5 Shabtai F, Kear D, Zohar I, Halbrecht I. Paracentric inversion in the long arm of chromosome X. Clin Genet 1983;23:245-6.

${ }^{6}$ Herr HM, Horton SJ, Scott CI. De novo paracentric inversion in an X chromosome. J Med Genet 1985;22:140-53.

7 Kim HJ, Hsu LYF, Hirschhorn K. Familial X/X translocation: $\mathrm{t}(\mathrm{X} ; \mathrm{X})(\mathrm{p} 22 ; \mathrm{q} 13)$. Cytogenet Cell Genet 1974;13:454-64.

Correspondence and requests for reprints to Mrs I C S Barnes, Centre for Human Genetics, 117 Manchester Road, Sheffield S10 5DN.

\title{
Martsolf's syndrome in a non-Jewish boy
}

\author{
P STRISCIUGLIO*, M COSTABILE*, M ESPOSITO $\dagger$, AND S Di MAIO* \\ Department of Paediatrics* and Institute of Public Medicine and Social Security \\ University of Naples, Naples, Italy.
}

SUMMARY Martsolf's syndrome has been described in Jewish people. We describe a patient of non-Jewish ancestry who has minor differences from other patients. The possible pattern of inheritance is discussed.

In 1978, Martsolf et $^{1} \mathbf{l}^{1}$ described two brothers, born to consanguineous Jewish parents, with severe mental retardation, cataracts, short stature, and primary hypogonadism. Another Jewish family with the same syndrome has recently been described. ${ }^{2}$ We describe here a non-Jewish boy, to clarify the clinical picture of this syndrome further and to determine its mode of inheritance which is still uncertain.

\section{Case report}

The proband was a 13 month old male, born to a G1 P1 A0 20 year old woman after an uncomplicated term pregnancy. There was no exposure to any known teratogenic agents during pregnancy. Delivery was uncomplicated and spontaneous. His birth weight was $2100 \mathrm{~g}$. The parents, of non-Jewish origin, were healthy and non-consanguineous.

There was no family history of other congenital malformations. At three months of age, the patient was admitted to hospital because of bronchopneumonia and retardation of growth. On this

Received for publication 5 December 1986

Revised version accepted for publication 1 April 1987. occasion bilateral cataracts were noted and at the age of seven months he underwent a surgical operation for these. At 13 months of age, he was admitted to our hospital because of growth and psychomotor retardation. On admission, physical

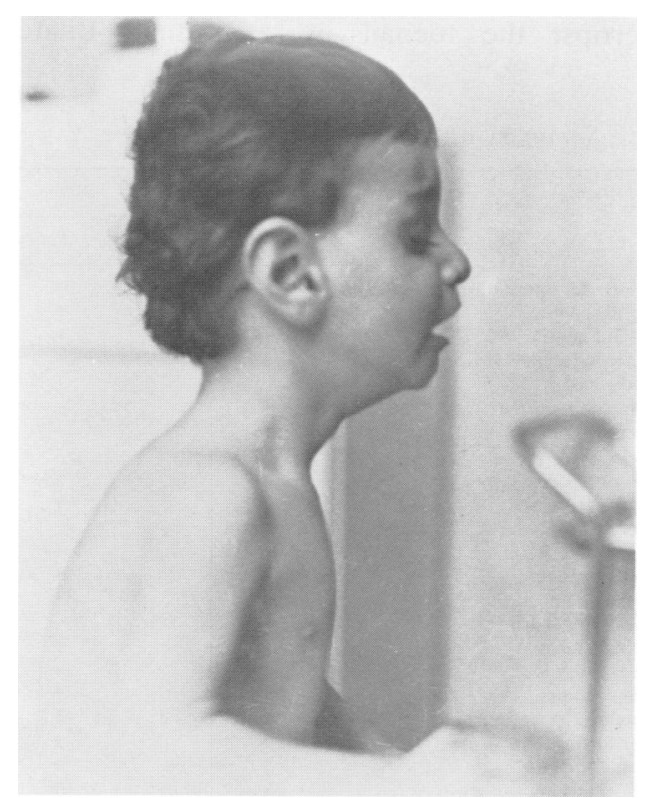

FIG 1 The proband at 13 months of age. 


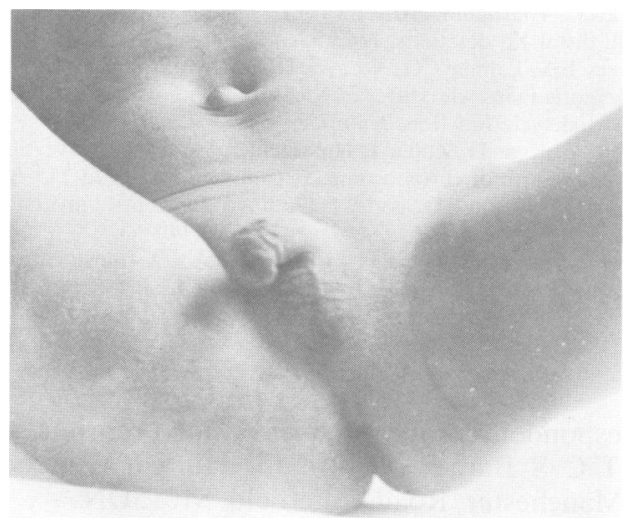

FIG 2 Genitalia of the proband at 13 months of age.

examination showed a boy with dysmorphic features (fig 1). His weight was $7000 \mathrm{~g}(<3$ rd centile), length $74.4 \mathrm{~cm}$ (10th centile), and head circumference 42.5 $\mathrm{cm}$ ( $<3 \mathrm{rd}$ centile). He had brachycephaly, flat occiput, low nasal bridge, mild micrognathia, low posterior hairline, normal philtrum, normal tongue, absence of hypotelorism, and a high arched palate. Pectus excavatum with normal nipples and mild lumbar lordosis were present as well as lax finger joints. Dermatoglyphic analysis showed absence of simian lines on the palms which were otherwise normal and six whorls and four ulnar loops on the fingertips; the toenails were normal. Bilateral cryptorchidism was present (fig 2), but the penis was normal (stretched penile length $5 \mathrm{~cm}$ ). Neuro $\overrightarrow{\vec{c}}$ logical evaluation showed psychomotor develop=ment corresponding to six months of age. $X$ ray and cardiovascular studies were normal. TORCHen and urinary amino acid, mucopolysaccharide, anc oligosaccharide patterns were normal. Basal values of FSH $(2.7 \mathrm{mUI} / \mathrm{ml})$, LH $(5.7 \mathrm{mUI} / \mathrm{ml})$, ands testosterone $(10 \mathrm{ng} / \mathrm{dl})$ were normal for age. Leydigo cell reserve after HCG stimulation test (2000 UI $x-$ three days) ${ }^{3}$ was normal (testosterone $200 \mathrm{ng} / \mathrm{dl}$ ) $\vec{\omega}$ Chromosome analysis showed a normal male karyotype.

\section{Discussion}

Martsolf's syndrome with its rather non-specifig features is a very difficult syndrome to diagnose? However, the presence of severe mental retardation cataracts, short stature, microcephaly and bilaterat cryptorchidism suggest that our patient has the syndrome, despite some minor differences (table) $)_{\infty}^{\infty}$ In our young patient the principal clinical signs of the syndrome are already present and his dermator glyphic pattern is similar to those of other patients. ${ }^{1}$ However, he differs from some of the patien described previously ${ }^{4}$ in whom other clinical signo were present besides the cataracts, mental re tardation, and hypogonadism.

Our patient, although having bilateral crypoํㅗㅇ orchidism, has a normal reserve of Leydig cells so far; follow up will be necessary to show primar

TABLE Summary of clinical findings.

\begin{tabular}{|c|c|c|c|c|c|}
\hline \multirow[t]{2}{*}{ Clinical findings } & \multicolumn{2}{|l|}{ Martsolf et al ${ }^{\prime}$} & \multicolumn{2}{|c|}{ Sanchez et at } & \multirow[t]{2}{*}{ Our patient } \\
\hline & Patient BS & Patient SS & Case 1 & Case 2 & \\
\hline Severe mental retardation & + & + & + & $?$ & + \\
\hline Height 3rd centile & + & + & + & - & - \\
\hline Weight 3rd centile & + & + & + & - & + \\
\hline Head circumference 3 rd centile & + & + & + & + & + \\
\hline Brachycephaly & + & + & + & + & + \\
\hline Aged appearance & + & + & + & $?$ & - \\
\hline Cataracts & + & + & + & + & + \\
\hline Hypotelorism & + & - & - & - & - \\
\hline Low nasal bridge & $?$ & + & - & - & + \\
\hline Maxillary retrusion & + & + & + & + & + \\
\hline Short philtrum & + & - & + & - & - \\
\hline Malaligned teeth & + & + & + & $?$ & $?$ \\
\hline Furrowed tongue & + & + & - & $?$ & - \\
\hline Sparse facial hair & + & + & $?$ & $?$ & $?$ \\
\hline Low posterior hairline & + & - & + & $?$ & + \\
\hline Flat broad sternum & + & + & + & + & - \\
\hline Prominent nipples & + & + & - & - & - \\
\hline Lax finger joints & + & + & + & + & + \\
\hline Short palms & + & + & + & + & - \\
\hline Lumbar lordosis & + & + & + & + & + \\
\hline Abnormal toenails & + & + & - & - & - \\
\hline Talipes valgus & + & + & + & + & + \\
\hline Hypogonadism & + (primary) & + (primary) & + & + & $?$ \\
\hline
\end{tabular}


involvement of the gonads. In contrast, the patients of Martsolf $e t$ al $^{1}$ showed clear evidence of primary hypogonadism. Possible hypogonadotrophic hypogonadism cannot be ruled out as a cause of hypogenitalism in the patients of Sanchez et al. ${ }^{2}$ Finally, our case, the only patient of non-Jewish ancestry reported so far, points to the likelihood that this syndrome does not affect only Jewish people. The fact that our patient is also male suggests two possible patterns of inheritance: $\mathrm{X}$ linked recessive inheritance or autosomal recessive inheritance with expression limited to males. However, the fact that only males seem to be affected might be a coincidence, since very few cases have been reported. It is evident that further reports are necessary in order to establish the exact pattern of inheritance, to clarify the type of hypogonadism and the clinical picture of this syndrome, and to discover whether this new syndrome affects mainly Jewish people.

\section{References}

${ }^{\prime}$ Martsolf JT, Hunter AGW. Haworth JC. Severe mental retardation, cataracts, short stature and primary hypogonadism in two brothers. Am J Med Genet 1978;1:291-9.

2 Sanchez JM, Barreiro C, Freilij H. Two brothers with Martsolf's syndrome. J Med Genet 1985:22:308-10.

${ }^{3}$ Winter JSD, Taraska S, Farman C. The hormonal response to HCG stimulation in male children and adolescents. J Clin Endocrinol Metab 1972;34:348-53.

4 Lubinsky MS. Cataracts and testicular failure in three brothers. Am J Med Genet 1983;16:149-52.

${ }^{5}$ Mikati MA, Najjar SS, Melham RE, Mansour S, Der Kaloustian VM. Microcephaly, hypergonadotrophic hypogonadism, short stature and minor anomalies: a new syndrome. Am J Med Genet 1985;22:599-608.

Correspondence and requests for reprints to $\mathrm{Dr}$ Pietro Strisciuglio, Clinica Pediatrica, II Facoltà di Medicina e Chirurgia, Via S Pansini 5, 80131 Naples, Italy. 